\title{
Improving Students' Vocabulary Through Words Games at Grade VI of SDS Setia Padang
}

\author{
Athessa Widya Arwandi ${ }^{1 *}$, Hermawati Syarif ${ }^{2}$, Havid Ardi $^{3}$ \\ ${ }^{1}$ Faculty of Languages and Arts, Universitas Negeri Padang, Indonesia, athessawidya62@gmail.com \\ ${ }^{2}$ Faculty of Languages and Arts, Universitas Negeri Padang, Indonesia, hermawati_sy@fbs.unp.ac.id \\ ${ }^{3}$ Faculty of Languages and Arts, Universitas Negeri Padang, Indonesia, havid_a@fbs.unp.ac.id \\ *Corresponding Author: athessawidya62@gmail.com
}

\begin{abstract}
The problem of this research is based on the phenomena of students at VI class of SDS Setia Padang. Based on the observation, the students' still have lack of vocabulary. There are various teaching methods have been offered by the experts, one of them is through of word games. Word games mostly used as it can motivate your learners English. Therefore, this paper explore how word games can be used to improve students' vocabulary mastery at elementary school level. This study applied classroom action research by using two cycles to find how word games increase the vocabulary mastery of the English language learner at elementary school. The results of pre-cycle show that the score of leaners' vocabulary mastery is 59 before the treatment. After implementing word game in teaching, the score of the students' is increased into 68.6. Then, the score in average is increased into 81.7 in the second cycle. Based on these data, the average scores of students are getting improved after they were taught by using word games. Based on the scores obtained, it indicates that the achievement of the students' vocabulary mastery is getting better. It can be concluded that word games can be used to improve the vocabulary mastery. Moreover, word games is also able to attract students' interest and motivation. Thus, by using Word Games as a medium for learning English for sixth grade can also foster confidence.
\end{abstract}

\section{Keywords: Teaching Vocabulary, Word Games}

\section{INTRODUCTION}

Vocabulary is very important in learning a foreign language, including English as one of compulsory foreign languages offered in Indonesian curriculum for junior and senior high school but it is not compulsory in primary schools (Zein, 2017; Chodijah, 2008). However, getting a numerous vocabulary is not an easy thing for most of the Indonesian students. As a result, students who lack vocabulary will have difficulty understanding text, cannot speak English, and are difficult to write their own ideas.

Lack of vocabulary mastery will make the students feel insecure in learning the foreign language, especially in elementary school. Sometimes, an elementary school student who has just learned vocabulary or only reads text or opens a dictionary will be able to say something (Harmer, 2001: 13). In addition, students with lack of vocabulary also read slowly because they do not understand many words or have to stop and look for them in a dictionary (Edwards, 2006: 177).

There are still many students who still lack of vocabulary, even though it is an important language component that should be mastered by students. In fact, there are still many students who asked the teacher to translate the question into their native language since the students did not understand the vocabulary in English.
Furthermore, the students did not know the content of the text that they read, so they cannot answer the question. This problem happened because they did not know the meaning of the text that written in English. In line with their writing ability, the students still depends on dictionary whenever they are asked to make a paragraph. Likewise, the problems happen on their listening and speaking ability. When the teacher asked them to answer some questions in English, some students may understand the meaning but they cannot answer it in English.

In improving student achievement in the teaching-learning process, teachers have an important role. The teacher must understand the condition of the students. An interesting method can make students happy in learning. The teacher must have the right method in the teaching-learning process.

There are some research related to the use interesting activity, such as, sing songs, role play, telling story (Hawanti, 2011). Moreover, some researchers propose game in language learning, (Kasri \& Ardi, 2013; Yuliasandra \& Ardi, 2013). It indicates that games are one of the methods that makes students happy and confident in learning, especially learning English.

This research aims to; to find out the word play implementation for sixth grade of SDS Setia Padang and to know the effectiveness of word play in teaching 
vocabulary for sixth grade of SDS Setia Padang. This research is expected to increase knowledge about word games in class activities. Researchers also hope that this research will benefit students, teachers, and writers.

Vocabulary games are great way to improve student vocabulary ability. To learn the vocabulary, there are many ways that the students can do. One of them is a word game. Students are very happy if the vocabulary game uses the game method. Necessary to remember, if we relax and have fun in learning, so the lesson will be much easier to be understood. The lesson will be difficult if the students are not enjoy and forced.

Read (2004) explains that in recent trend of vocabulary assessment, the assessment not only focus on vocabulary knowledge (form and meaning), but also the usage. Furthermore, Bachman and Palmer, as excerpted by Read (2000), says that even in elementary level the test should be in context to assess the communicative ability (use), for example, in "going to the zoo" topic not only test the names of animals, but also test some meaningful use of language outside the classroom.

The people sometimes considered that in order the students learn well, they need to study seriously. Actually, that way of teaching should not always to be so serious. The concept of learning should be serious is a misconception. Therefore, games is the activity that provide interesting and fan activity for the students in learning English.

Word games are ordinarily used as a source of entertainment, but it can be used for educational purposes too. Children, for example, can have the pleasure by using games, such as, word search, hangman, and word puzzle. Naturally, it makes students skilled in spelling. Solving crosswords, which requires patience and familiarity with larger vocabulary has better brain function later on (Dunbar, 2018). Word games are great media for students to have interesting activity with words. They can practice spelling skills and arrange the vocabulary. The games that can be choose such as such as Crosswords, Jumble, Word Searches, word chain, and so on.

Based on the background above, the researchers are interested to use word game as media to improve students' vocabulary. The students can build vocabulary and speaking skills. The researchers decided not to use all type of word games. The researchers only chose some of interesting, attractive, simple, and appropriate for sixth-grade students. Based on the criteria, the researchers chose shiritori, word chain, and word clap.

\section{METHOD}

Classroom Action Research (CAR) was implemented to see the improvement of students vocabulary mastery at the fifth-grade students of SDS Setia Padang. This school is located at Elang Street, Air Tawar Barat, Padang. The researcher chose SDS Setia because the school where the researcher teaches. The students came from different types of characteristic. Data were collected while teaching practice within two cycles. The researchers conducted preliminary research in first week. Then, the researcher conducted teaching practice for the two cycles.

In this classroom action research, the researcher conducted two cycles by using some types word games. The cycles consist of four stages. The stages are planning, acting, observing, and reflecting.

The key instrument in this research was the researcher herself as a teacher she involved in every step in the cycle. There were two instruments use in this research; observation sheet and vocabulary test. Observation sheet was designed before the research. It used to record and collect real information of teaching and learning process during conducting of the research. This observation form was fulfilled by the collaborator and researcher. In doing this observation the crucial components were highlighted such as, setting, participant, activity and number of vocabulary master by the students as well as the duration. The vocabulary test was conducted at the end of each cycle to see the improvement of student's vocabulary mastery. The students are asked to write down the vocabulary that they have studied in the word games.

After collecting the data, the researchers then analyzed the data. They were observation and vocabulary test. The observation was done to see the basic capability of students' vocabulary. The test was given to the students to see their vocabulary improvement.

\section{RESULTS AND DISCUSSION 3.1 Result}

The result of research showed that word games strategy gave better result on students' vocabulary. It can be seen from the hypothesis is:

Table 1. Score of treatment

\begin{tabular}{|c|c|c|c|c|c|}
\hline N & $\begin{array}{c}\text { Total } \\
\text { Score }\end{array}$ & $\begin{array}{c}\text { Maximal } \\
\text { Score }\end{array}$ & $\begin{array}{c}\text { Minimal } \\
\text { Score }\end{array}$ & Mean & $\begin{array}{c}\text { Level } \\
\text { Ability }\end{array}$ \\
\hline 22 & 1298 & 90 & 25 & 59 & Mediocre \\
\hline
\end{tabular}

In pre-cycle, the mean score of students' vocabulary was 59. It can be classified as less than minimum criteria of mastery learning (KKM). Since minimum criteria of mastery learning in SDS Setia Padang was 76. The mean score of students in pre cycle was lower than KKM. Thus, the researcher needed to give treatment to the students to improve their vocabulary achievement. Therefore, based on the average vocabulary in the class, the level of ability is mediocre.

Table 2. The level ability

\begin{tabular}{|c|c|c|c|c|c|}
\hline N & $\begin{array}{c}\text { Total } \\
\text { Score }\end{array}$ & $\begin{array}{c}\text { Maximal } \\
\text { Score }\end{array}$ & $\begin{array}{c}\text { Minimal } \\
\text { Score }\end{array}$ & Mean & $\begin{array}{c}\text { Level } \\
\text { Ability }\end{array}$ \\
\hline 22 & 1510 & 93 & 40 & 68,6 & Good \\
\hline
\end{tabular}

In first cycle, the mean score of students' vocabularies was 68,6 . It was from that mean score was still less than minimum standard achievement. Therefore, the researcher supposed to conduct to second cycle after evaluating 
process. Then, based on the average vocabulary in the class, the level ability is Good.

Table 3. Score of the ability

\begin{tabular}{|c|c|c|c|c|c|}
\hline N & $\begin{array}{c}\text { Total } \\
\text { Score }\end{array}$ & $\begin{array}{c}\text { Maximal } \\
\text { Score }\end{array}$ & $\begin{array}{c}\text { Minimal } \\
\text { Score }\end{array}$ & Mean & $\begin{array}{c}\text { Level } \\
\text { Ability }\end{array}$ \\
\hline 22 & 1799 & 96 & 70 & 81,7 & Excellent \\
\hline
\end{tabular}

In second cycle, the mean score of students' vocabulary was 81,7 . The result in this cycle can be stated as good because the mean score was more than 76 (minimum standard achievement). The result of the vocabulary test indicated that there was an improvement compared to the previous cycle.

Based on the mean score of students' vocabulary in the second cycle, it can be assumed that the ability of students' vocabulary was successful. Based on the average vocabulary in the class, the level ability is excellent.

\subsection{Discussion}

The researcher did this research improve students' vocabulary through word games at grade V of SDS Setia Padang. The researcher expected that this research improve students' vocabulary because the student's vocabulary was low and did not reach minimum standard achievement score.

The results of pre-cycle show that the average score of the students' is 59. After implementing word game in teaching, the score is increased into 68.6. Then, the score is increased into 81.7 in the second cycle.

Based on these data, the average scores of students are getting improved after they were taught by using word games. Based on the scores obtained, it indicates that the achievement of the students' vocabulary mastery is getting better.

This condition is relevant with opinion that the use of game in language learning, (Kasri \& Ardi, 2013; Yuliasandra \& Ardi, 2013; Hawanti, 2011). The findings above also show that word games can improve students' vocabulary.

In relation to research question "How can Word Games improve students' vocabulary achievement to the fifth-grade students of SDS Setia Padang?" The extent of improvement of vocabulary through word games of grade $\mathrm{V}$ average score was from 59 in pre cycle to 81.7 at the end of cycle II. The extent of improvement was good (59 to 81.7). the word games succeed to improve students' vocabulary from the score below the minimum standard achievement score to reach the minimum standard achievement score that was 76.

It can be concluded that word games can be used to improve the vocabulary mastery. Moreover, word games is also able to attract students' interest and motivation. Thus, by using Word Games as a medium for learning English for sixth grade can also foster confidence.

Based on the discussion, this classroom research is success to improve the students' vocabulary. The improvement of vocabulary is significance. The extent of improvement from cycle one to cycle two is 68.6 to 81.7 . It raised the students' achievement score of vocabulary.

\section{CONCLUSION}

Based on discussion above, research discover that the Word Games can be used to increase the vocabulary mastery of the students well. It can be seen from the previous chapter which explained Word Games media has good result on student's vocabulary achievement. Thus, the students have enthusiasm in teaching learning process. Then, the students have better self-confident than before. It is because game make them relax in learning process (Toth, n.d.).

\section{ACKNOWLEDGMENT}

The authors would like to express their gratitude to the head master of SDS Setia Padang, for the chance given to conduct this research.

\section{REFERENCES}

[1] Arsyad, A (2003). Media Pembelajaran $1^{\text {st }}$ Ed., p. 15.

[2] Brown, D. (2005). Principles of Language Learning and Teaching. New York: Pearson Education

[3] Chodidjah, I. (2008). Scrutinizing the teaching of English in elementary schools in East Asian countries. Paper presented at the ASIA TEFL International Conference 2008, Bali, 1-3 August 2008.

[4] Danarti, D. (2008). 50 Games for Fun (belajar bahasa Inggris dengan lebih menyenangkan. Yogyakarta: CV. Andi Offset.

[5] Harmer, J. (2001). The Practice of English Language Teaching. New York: Longman.

[6] Hawanti, S. (2011). Teaching English in Indonesian primary schools: The missing link. Leksika, 5(1), 62-69.

[7] Kasri, H., \& Ardi, H. (2013). Using crazy story game in teaching speaking to junior high school students. Journal of English Language Teaching, 2(1), 120-126.

[8] Lyle, D. (2016). Benefit of solving puzzle http://m.dummies.com/how-to/content/benefits-ofsolving- puzzle.html.

[9] Nation, Paul. (2005). Teaching Vocabulary. In Asian EFL Journal (Online): Vol 7, Issue 3, pp. 47-54. available: http://www.asian-efl-journal.com/September_05_p n.php .

[10]Nation. Paul (2002). Current Research and Practice in Teaching Vocabulary. In Jack.C. Richards \& Willy.A. Renandya. (Eds), Language Teaching Methodology (pp. 269-270). 
[11]Pearson, P.D, Hiebert, E.H \& Kamil, M.L. (2014). Vocabulary Assessment: What We Know and What We Need to Learn.

[12]Read, John. (2004). Second Language Vocabulary Testing: Taking a Broader Perspective.

[13] Sokmen, Anita J. (2005). Current Trends in Teaching Second Language Vocabulary. In Norbert Schmitt \& Michael McMcarthy. (Eds), Vocabulary: description, acquisition and pedagogy.

[14]Xiang, M.Z. (2000). The Necessity of Intensifying English Vocabulary Teaching in Remote Minority Area Collage English Teaching. In Asian EFL Journal.
[15] Yuliasandra, N., \& Ardi, H. (2013). Enhancing senior high school students' ability in writing descriptive text through Lang 8.

[16]Zein, M. (2017). Elementary English education in Indonesia: Policy developments, current practices, and future prospects: How has Indonesia coped with the demand for teaching English in schools? English Today, 33(1), 53-59. doi:10.1017/S0266078416000407 